\title{
IMAGES AND REPRESENTATIONS OF THE RUDNYTSKYI FAMILY: The Case of Ukrainians in Galicia Between the Wars
}

\author{
Illia Chedoluma \\ iD https://orcid.org/0000-0003-3445-6244 \\ (Ukrainian Catholic University in Lviv, Ukraine) \\ e-mail: chedoluma@ucu.edu.ua
}

Keywords: images, Galicia, interwar period, the Rudnytskyi family, Jews

\begin{abstract}
Caricature journals in the interwar period had a special genre niche, giving the masses, through funny cartoons, a simplified understanding of internal and external political processes. $Z y z$ and Komar were the largest Ukrainian satirical humor journals in interwar Galicia. They mainly covered the internal political life in the Second Polish Republic and international relationships. These journals are primarily intended for people from the countryside, and the editors and owners of these journals used anti-Semitism for the political mobilization of the rural population. I use elements of Serge Moscovici's theory of social representations to track these processes.

A key aspect here is how the image of the Rudnytskyi family was shaped on the pages of these journals. The family was of mixed Ukrainian-Jewish origins, and its members became prominent figures in various spheres of Ukrainian social and political life in interwar Galician Ukrainian society (in politics, literature, music, and the women's movement). The behavior of the Rudnytskyi family was explained to the readers through their Jewish origins. Zyz and Komar both created an image of the Rudnytskyis as an integral Jewish group occupying different spheres of Ukrainian life. The study of visual caricature images thus enables us to explore the channels of the formation and spread of anti-Semitic images of Jews and the use of the image of "the Jew" in the Galician Ukrainian society in interwar Poland.
\end{abstract}

Never forget what you are, for surely the world will not. Make it your strength. Then it can never be your weakness. Armor yourself in it, and it will never be used to hurt you.

(George R.R. Martin, A Game of Thrones)

Some people have divided other human beings into the categories of "Our" and "Other" for centuries, if not throughout history. Determining who is "ours" and who is "alien" is one of the basic rationales behind identifying individuals in a society. In the context of the history of Ukraine, the question has arisen from time to time: Who is a real "Ukrainian" and who is not? By what criteria to is it determined: racial, ethnic, linguistic, political? Exploring different approaches to the analysis of "other" concepts and identities, Iver B. Neumann argues that "Other" sociological margins play an important role in 
the formation of collective identity, since their presence raises the question of who is "I" and who for me is the "Other." One example of such an issue directly concerns a family well-known to Galician interwar society - the Rudnytskyis.

The Rudnytskyi family here refers to the children of the lawyer Ivan Rudnytskyi (1856-1906) and Olga Rudnytska (née Ida Spiegel, 1864-1950). Their marriage provided Ukrainian society with a whole galaxy of well-known Galician cultural and political figures, including writer, publicist and translator Mykhailo Rudnytskyi (1889-1975), political activist and organizer of the Ukrainian women's movement Milena Rudnytska (1892-1976), politician and journalist Ivan Kedryn-Rudnytskyi (1896-1995), composer and musician Anton Rudnytskyi (1902-1975), and lawyer Volodymyr Rudnytskyi (1890-1974). In spite of the numerous studies devoted to various aspects of the biographies and activities of the family members, ${ }^{2}$ there are unfortunately no studies that relate directly to the history of this family. Just as this is a task for a particular monographic study, the purpose of this paper is much more modest - to trace and analyze ways of constructing an image and representations of a group of persons in their surrounding society, on the example of the Rudnytskyi family in interwar Galicia. The study will primarily concern the group with which the Rudnytskyi family identified: Galician Ukrainians.

Let us attempt to answer the following questions: How was the Rudnytskyi family perceived in different circles of Galician society? What images of the family existed during the interwar period? In what way did the images of the family spread to the surrounding society? Social representations should be seen as a specific way of understanding and communicating. Representation equals image/meaning; in other words, that it equates every image to an idea and every idea to an image. ${ }^{3}$ That is, the imagination has two aspects - conceptual and iconic. This duality of aspects of representation is important in social analysis since the simplified, iconic aspect is accessible to the masses, while that of the privileged classes is more complicated, more conceptual. However, it should be remembered that the image and the representation are inseparably linked in the view: each representation corresponds to the image, each image to the representation. ${ }^{4}$ Moscovici's social view consists of three components: 1) Information - a body of knowledge about the object, obtained from various sources (media, educational, institutions, etc.), 2) Representation - which is formed in a group and is inseparable from it, and 3) The relation between the person represented and the object of the imagination. ${ }^{5}$

\section{"The Unusual Union": A short history of the Rudnytskyi family}

Ivan Rudnytskyi was born in 1855 in the village of Dunaev (now in the Peremyshlyany district of Lviv region, Ukraine), where his father Mykhailo was a priest. Ivan

\footnotetext{
${ }^{1}$ Neumann 1999: 11; More on the image of "Other" can be found here: Neumann 1998: 26-73; Neumann 1996.

2 Hrytsak 1994: 73-96; Sawa 2016; Bohachevsky-Chomiak 1988; Diadiuk 2011; Hnatiuk 2019; Gnoiński 2012; Kvit 1997.

${ }^{3}$ Moscovici 2001: 31.

${ }^{4}$ Ibid.

${ }^{5}$ Moskovychy 1995.
} 
graduated from school and gymnasium in Berezhany. He studied law at the University of Lviv and later served in the 55th infantry regiment, fighting in the military campaign of Habsburg's troops in Bosnia in $1878 .{ }^{6}$ In the same year, while in military service in Lviv, Ivan Rudnytskyi met a young girl from a Jewish family, Ida Spiegel. Ida's parents owned a small shop in Zamarstynivska Street. ${ }^{7}$ Their dating evolving into a serious relationship, the couple decided to get married, but were met with strong resistance from both families. It was an unacceptable and eternal shame for Ida's parents to betray their daughter for a "Goy." This marriage could only be possible if Ida were to convert. That is, in the Jewish tradition she would cease to be Jewish and would not exist in the eyes of the Jewish community. However, Ivan's family, mainly his mother Carolina, objected to the relationship as well. After all, the only son of the priest Mykhailo Rudnytskyi and a respected matron of a Polonized German family could not be allowed to marry a girl from the "Jewish Ghetto." 8

Nonetheless, ten years after they first met, in the early spring of 1888 the young couple got married. Before that, Ida had fled from her parent's home, hiding in the Benedictine Sisters Monastery for some time, where she underwent catechesis, was converted into Christianity and was given her new name of Olga. It is worth noting that this story is an exception rather than the rule. Mixed marriages were not uncommon in the borderlands, and Galicia at the end of the 19th and the beginning of the 20th century was no exception, with numerous examples of mixed Polish-Ukrainian and Polish-Jewish marriages; however, Ukrainian-Jewish mixed marriages were rather a rarity. ${ }^{9}$ Accordingly, this created additional difficulties for the young couple. Tracing their children's places and dates of birth reveals numerous relocations, which stands as indirect confirmation that the young family was not immediately able to successfully integrate into the milieu.

The eldest son Mykhailo was born in Podgajtsy (6 January 1889). From there, the family moved to Zboriv, where Volodymyr (15 November 1890) and Milena (15 July 1892) were born. Later, the family moved from Zboriv to Zolochiv, and from there to Khodorov where Ivan was born (22 April 1896). Subsequently, the Rudnytskyi family lived for some time in Mykolaev above the Dnister River in the village of Luky (near Sambir), where their daughter Maria was born (and died a few days later). The youngest son Anton was also born in Luky (15 January 1902). From 1903 to 1907, the Rudnytskyi family lived in Berezhany. ${ }^{10}$ A year after the unexpected death of the head of the family, Ivan Rudnytskyi, in 1906, his widow Olga moved to Lviv with the children. The frequent relocations were likely caused not only by the specifics of Ivan's profession as a lawyer but also by the fact that the family, given the origins of his wife, for a long time could not integrate into the rather conservative and traditional micro-world of the Ukrainians of small-town Galicia.

It is worth noting that sometime in the late 1890s Olga Rudnytska was able to re-establish relations with part of her family, including her brother Max and sister Tinka, who came to visit the Rudnytskyi family. At the same time, her brother and sister continued

\footnotetext{
6 Rudnytskyi 1970: 363.

7 Rudnytska 1998: 46.

8 Ibid.

9 Vovchko 2016.

10 Rudnytska 1998: 56.
} 
to call Olga by her old Jewish name of Ida. ${ }^{11}$ At the Rudnytskyi's home, the Polish language was spoken for a long time. Olga Rudnytska could not fully master the Ukrainian language by the end of her life, but in a later period, writing letters to her children, she always signed them in Ukrainian with "your mother Olga."12 The cooks hired by the Rudnytskyi's were Polish. In the gymnasium (particular in Berezhany) the language of education was also Polish at that time. Interestingly, the parents tried to raise their children in a spirit of tolerance towards other ethnic groups, and Volodymyr Rudnytskyi remembered his father's words: "love for one's people and work for them cannot be based on hatred for others." "13 Ivan Rudnytskyi was distinguished by this favorable attitude towards Jews, as evidenced by the fact that a young Jewish lawyer, Rawicz, worked in his office in Berezhany, ${ }^{14}$ and his daughter Milena was tutored by Jews named Price and Drux. Ivan Rudnytskyi was also fluent in Yiddish, which he spoke with his Jewish clients. ${ }^{15}$

However, the fact that Ivan and Olga Rudnytskyi raised their children in a tolerant spirit is evidenced by two interesting events surrounding their oldest son Mykhailo. The first happened in 1903: When news of a pogrom of the Jews in Chisinau reached Berezhany, the local Jewish community decided to have a memorial service in a large local synagogue. On behalf of the Ukrainian community, three people came forward to express their condolences: well-known local lawyer and political activist Volodymyr Bachynskyi (1880-1927) and two gymnasium students, Anton Chernetkyi (1998-1963) and Mykhailo Rudnytskyi (1889-1975). ${ }^{16}$ The second case occurred in 1907, when after the death of Ivan Rudnytskyi. Mykhailo Rudnytskyi stood up to the teacher to defend his classmate, a Jewish student named Landsman. The conflict became widely known, and Mikhailo Rudnytskyi was temporarily suspended from the gymnasium. As soon as the gymnasium students found out about it, one of them, a Pole named Alfred Bilyk ${ }^{17}$ (1889-1939) organized a strike in defense of Mykhailo Rudnytskyi. A few days later, the strike proved successful, as Mykhailo was reinstated into the gymnasium. ${ }^{18}$

The scope of this article does not allow us to cover the further period of life and activity of members of the Rudnytskyi family. It should be noted only that after the death of her husband was Olga Rudnytska able to provide all of her children with a proper education. Members of the Rudnytskyi family came to the forefront in the political and cultural life of Galician Ukrainians during the interwar period. Returning from abroad to Lviv in 1922, Mykhailo Rudnytskyi became a co-editor of the newspaper Dilo and several other journals, as one of the most renowned literary critics in Galicia. Milena Rudnytska became known as an organizer and activist of the Ukrainian women's movement and a member of the Ukrainian National Democratic Alliance (UNDO). Ivan Rudnytskyi, nicknamed "Kedryn," starting as a journalist at Dilo, eventually became a prominent member of UNDO. Anton Rudnytskyi gained fame as a composer, continually on

11 Ibid:: 47.

12 Kedryn 1976: 15.

13 Rudnytskyi 1970: 364.

14 Perhaps it was Solomon Rawicz, the father of a French writer Piotr Rawicz (1919-1982).

15 Rudnytska 1998: 54.

16 Charnetskyi 2001: 29.

17 Later, in the interwar period, Alfred Bilyk held high administrative positions in Poland, including Ternopil and Lviv Governor, see: Jarno 2018: 55-79.

18 Rudnytskyi 1970: 368; Kedryn 1976: 14. 
concert tours of Europe. Only Volodymyr Rudnytskyi decided to follow in his father's footsteps and become a lawyer; in the interwar period he did not take an active part in public cultural and political life. In this way the Rudnytskyi family became wellknown public figures and a media personalities in the 1920s, and especially in the 1930s.

\section{"Goes, goes Zelman...": The image of the Rudnytskyi's family in the satirical-humorous journals $Z y z$ and Komar}

The historian Mark Mazower famously dubbed interwar Europe, with its increasing anti-Semitism, violence, and flirtation with Communism and Nazism, the "Dark Continent." 19 Satirical journals specializing in caricature occupied a particular genre niche at that time, presenting to the masses a simplified understanding of internal and external political processes through ridiculous caricatures. The rise of anti-Semitic discourse in the public sphere increasingly led satirical journals to publish caricatures of Jews. The journal $Z y z$ was published from 1924 to 1932. The editors-in-charge were Osyp Bodnarovich (1925-1927), Volodymyr Kuchabckyi (1927), Roman Pashkovskyi (1928-1932, 1933) and Edward Kozak (1928-1929). The journal was published twice a month. ${ }^{20}$ Its successor Komar became the largest Ukrainian satirical-humorous journal in interwar Galicia, and it was published from 1933 to 1939. The editor-in-chief for almost the entire period of the journal's existence was Lev Chubatyi (from 1933 to 1938). However, one of the most famous Ukrainian cartoonists, Edward Kozak (1902-1992), played an important role in the creation, selection, and placement of cartoons in both journals. Ivan Gornyi and Ivan Kernytskyi also worked on issues of Komar. The journal was based on Ivan Tyktor's (1896-1982) concern, Ukrainian Press. Ivan Tyktor and Edward Kozak maintained close business contacts during this period. For example, Kozak illustrated almost all the books and periodicals published in Ukrainian Press. The journal printed over 7,000 copies a month. ${ }^{21}$

The main subjects of $Z y z$ and Komar were domestic political life in interwar Poland and international relationships. Aside from publishing some cartoons dedicated to the Polish authorities (some of which were confiscated), Komar's editorial staff focused on various aspects of Ukrainian political life in Lviv, including personalities. Numerous caricatures on stereotyped images of Galician Jews also appeared on the pages of $Z y z$ and Komar. ${ }^{22}$ There were even separate sections of "Jewish" humor. Most likely, the sources of inspiration for their cartoons were the anti-Semitic Polish journals. ${ }^{23}$ Answering the question of why artists engaged in anti-Semitic caricatures, Dariusz Konstantynow

19 Mazower 1999.

20 Snitsarchuk 2003b: 447-448.

${ }^{21}$ Snitsarchuk 2003a: 345-347. For the Ukrainian segment of the press in Galicia, this is a significant number, though the Polish anti-Semitic caricature-satirical journals were published in 40 and even 50 thousand copies, see: Konstantynow 2013: 1-131.

22 One of the most striking examples was on the first pages from $\mathrm{Zyz}$. One of them shows the Jewish colonization of Ukraine: $Z y z$ 1924, no. 3; In another, the Polish-Jewish agreement 1925 was presented in the form of a Jew who, for silver pieces, "sells" Ukrainians: Zyz 1925, no. 14.

23 More on anti-Semitic caricatures in the Polish interwar press, see: Konstantynow 2013: 1-131. 
notes that we should not reject one of the most trivial motives - that is, financial. For many, publishing cartoons in those types of journals was one way to make a living. ${ }^{24}$ It is plausible that the sympathies of the owners of the journals were rather on the side of Ukrainian integral nationalists, since no caricatures of them were published in these journals. Meanwhile, the "Jewish card" was played in the political struggle to create an image of the "Other": the liberal and left-wing Ukrainian political movements among the Ukrainian population. ${ }^{25}$ Not surprisingly, the Rudnytskyis, being prominent figures, became the subject of caricature. It is interesting what images appeared in these caricatures.

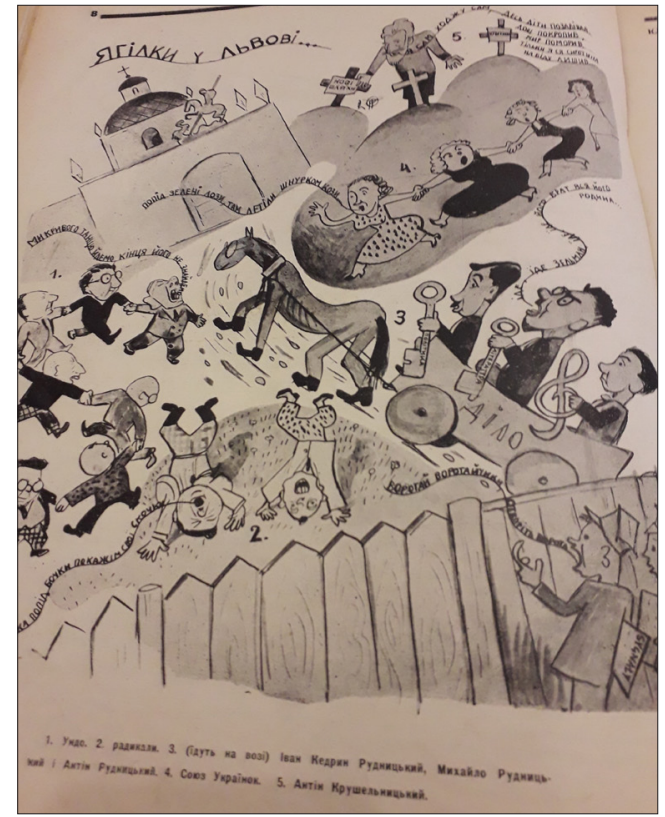

Figure 1. "Yagilki in Lviv." Image of the Rudnytskyi family as a group that occupied different spheres of Ukrainian life in interwar Galicia.

Source: Komar 1934, no. 7.

The depictions of the Rudnytskyi family can be divided into two categories: caricatures of individual members of the Rudnytskyi family, and caricatures of the Rudnytskyis

${ }^{24}$ Konstantynow 2013: 6.

25 Bright illustrations of this thesis were caricatures in which Ukrainian political and public figures of the liberal and left positions were depicted as "Jews": Komar 1933, no. 5; Komar 1933, no. 11; Komar 1933, no. 17; One of the most famous Ukrainian historians, Ivan Lysyak-Rudnytskyi, son of Milena Rudnytska, wrote in his diary about Tyktor's motives. Having met Ivan Tyktor in Krakow in 1940, LysyakRudnytskyi wrote that Tyktor no longer supported the nationalists because they did not allow him to publish. However, in the interwar period, especially in 1938-1939 in connection with events around the Carpathian Ukraine, Tyktor used attacks on the Rudnytskyi family, in particular on Milena, to receive a colossal profit. In his press, using "nationalistic phraseology and sauce," he gained more and more subscribers and large financial profits: Lysyak-Rudnytskyi 2019: 78. 
as a family. From the second category, among the most characteristic is a cartoon in Komar in 1934 entitled "Yagilki in Lviv." ${ }^{26}$ Readers were introduced to a cartoon reproduction of various groups in Lviv during this period. From the five different groups, the Rudnytskyis are represented in two (see Fig. 1). More precisely, one of the groups was the Rudnytskyis. Milena Rudnytska was showed separately as a leading Ukrainian woman. In the meantime, the three Rudnytskyi brothers (Ivan, Mykhailo, and Anton) were pictured on a wagon bearing the inscription "Dilo" and being pushed by one of its editors. Each of the brothers holds a key in his hand, symbolizing politics (Ivan), literature (Mykhailo), and music (Anton). A song comes from Mykhailo's mouth: "Goes, goes Zelman." ${ }^{27}$ These lines were from a song, well-known in Galicia from the turn of the 18th and 19th centuries, about Zelman (Zeev) Wolfovich - a real historical character, a Jew from Drohobych who lived in the XVIII century. ${ }^{28}$ Zelman was remembered by the people of Drohobych because he had managed to take control of the various spheres of the city's economic life, and his numerous families assisted him in doing so. In the end he was arrested and sentenced to death for fraud. ${ }^{29}$ The keys in the Rudnytskyis' hands were also a reference to a version of the song "Goes, goes Zelman," according to which Zelman and his family hold the keys to the temple and only with his consent could Christians enter the church and pray to God. ${ }^{30}$ Accordingly, an unknown caricaturist depicts the Rudnytskyis as a family who had captured various spheres of Ukrainian life, using Dilo as a platform to spread their influence. This behavior was explained as stemming from the Jewish origins of the Rudnytskyi family, as indicated by the song. Interestingly, we know the at least one reader's reaction to this cartoon. As soon as in the next issue a clipping made by one of the readers was published. ${ }^{31}$ In this version, Milena Rudnytska has joined the "Zelmans," riding the horse which pulls her family forward. ${ }^{32}$

The image of the Rudnytskyi's family as a cohesive group occupying different spheres of Ukrainian life was also reproduced in a cartoon captioned "Editorial Board of the New Women's Journal Women." ${ }^{33}$ In a similar way, the Rudnytskyi's family was also the subject of the cartoon "General Staff of Princess Olga's guard." 34 In general, the Rudnytskyi family was often portrayed as selfishly helping one another out of concern for their own interests, particularly in a caricature depicting Ivan Kedryn-Rudnytskyi and Osyp Nazaruk as athletes being judged by Ivan's brother, Mykhailo. ${ }^{35}$

However, in addition to these group caricatures, the images imposed on individual members of the family are interesting to explore. Ivan, Mykhailo, and Milena were the

26 Komar 1934, no. 7.

27 Ibid.

28 The image of "Zelman" was an important component of Galician Christian folklore about Jews, see: Pawłyszyn 2017.

29 Yide, yide Zelman abo Tsikava storinka $\mathrm{z}$ istorii Drohobycha.

30 "People gathered under the churches, And they stared intently at the roads: 'Oh, when will that Zelman arrive and let us into the saint's temple to pray to God?'." Ryndyk 1961. More about the "Keys to the Church" theme in: Shkandrij 2009: 11-19.

31 Komar 1934, no. 8 .

32 It is worth noting that the lyrics of "Goes, goes Zelman" have also been used in other Anti-Semitic cartoons. For example, in the caricature that is a visualization of the Judeo-commune myth: Zyz 1930, no. 8 .

33 Komar 1935, no. 3.

34 Komar 1938, no. 33.

35 Zyz 1931, no. 9. 
most frequent figures here. Let us dwell more on the caricatures of Ivan and Mykhailo, as they have several features in common. One way of emphasizing the Jewish origins of the Rudnytskyi family was to depict them wearing tallit prayer shawls. One of these cartoons depicted a collaboration between Ivan Kedryn-Rudnytskyi and the Polish journal Biuletyn Polsko-Ukrainski. ${ }^{36}$ Kedryn-Rudnytskyi is dressed in a tallit that protrudes from under his modern coat. Meanwhile, Milena and Mykhailo Rudnytskyi, along with several other Galician figures, are on the sidelines cheering him on.

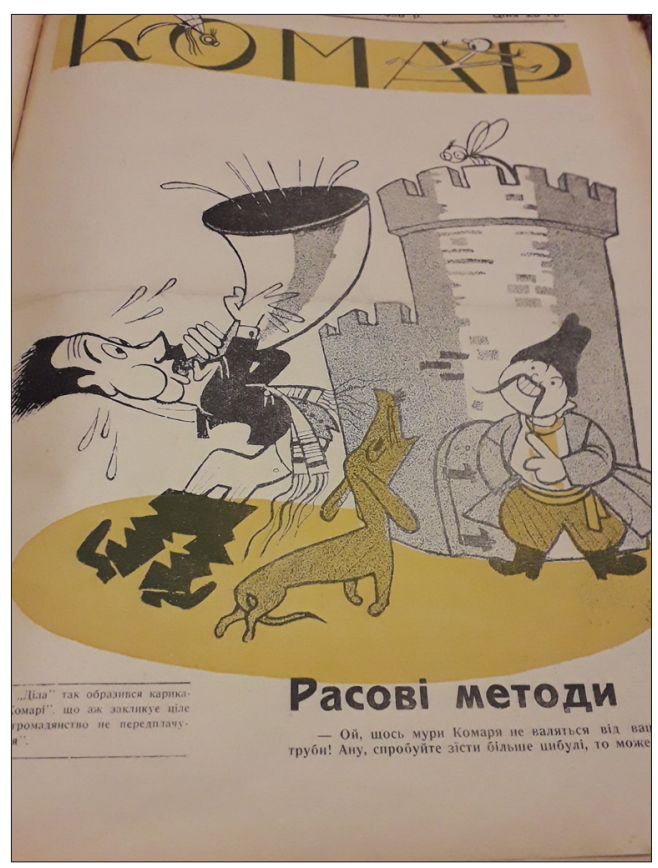

Figure 2. "Racial Methods." Ivan Kedryn-Rudnytskyi as an Old Testament Jew, alluding to the fall of the Walls of Jericho.

Source: Komar 1938, no. 44.

However, if previous caricatures merely hinted at the family's Jewish origins, in another one also dedicated to Ivan Kedryn-Rudnytskyi, they are referred to directly by the title, "Racial Methods" (see Fig. 2). The context of this caricature is simple: a cartoon in Komar made and signed by Edward Kozak angered Ivan Kedryn-Rudnytskyi and he decided to respond publicly, urging a boycott of Komar. ${ }^{37}$ In response, Komar's editorial staff published a cartoon alluding to the fall of the Walls of Jericho. In the cartoon Kedryn-Rudnytskyi is trying to blow his horn like an Old Testament Jew, but the walls, on the top of which sits a mosquito symbolizing the journal, do not fall. Kedryn-Rudnytskyi was again dressed in a tallit. In front of the walls stands a stereotypical

\footnotetext{
36 Komar 1935, no. 5.

37 Komar 1937, no. 37.
} 
Ukrainian laughing at his efforts. ${ }^{38}$ The titles and contents of the caricatures led readers to interpret the Rudnytskyis in only one way: as alien to the Ukrainian nation. One of the following issues published a caricature with a long article called "Renters," to reinforce this thesis in the reader's imagination (see Fig. 3). ${ }^{39}$ The Rudnytskyi family was portrayed as typical Oriental Galician Jews who gathered at the table to discuss how best to cheat the Ukrainians and whether or not to flee from Galicia to Palestine in the face of the threat from Hitler. The idea that the Rudnytskyis feared Hitler because of their Jewish origins arises in another caricature of them. ${ }^{40}$ These cartoons were closely linked to the increasingly positive image of Hitler painted by Komar in the late 1930s (see Figs. 4 and 5$).{ }^{41}$

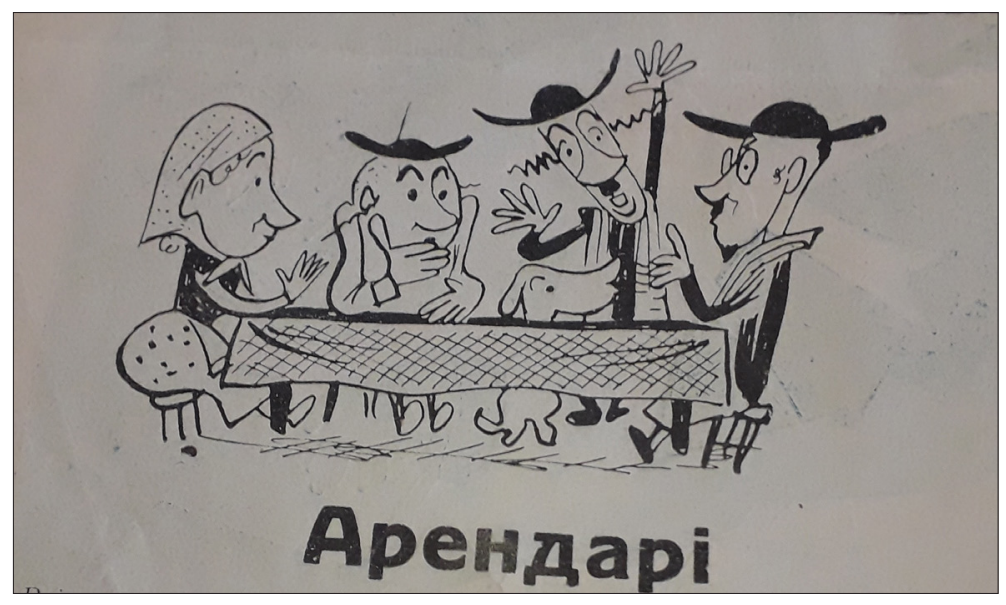

Figure 3. "Renters." Image of the Rudnytskyi family as "Jews-Renters," discussing how best to cheat the Ukrainians.

Source: Komar 1938, no. 45.

The same stereotypical image was presented in caricatures and texts about Mykhailo Rudnytskyi. In one of the most famous, Mykhailo is depicted in the image of a "Jewmason," who has thrown a tallit on top of his costume and is performing an obscure rite over Ukrainian culture, as represented by a grave with seven candles. From time to time, he pulls from the grave "rotten" ideas such as liberalism and freedom of individuality (see Fig. 6). ${ }^{42}$ In another caricature, one dedicated to Mykhailo Rudnytskyi's literary review of poems by Oles Babyi, Rudnytskyi is portrayed as a Pharisee Jew insisting on the death of Babyi. ${ }^{43}$

\footnotetext{
38 Komar 1938, no. 44.

39 Komar 1938, no. 45.

40 Komar 1938, no. 44.

41 The clearest example of creating a "positive" image of Hitler among Galician Ukrainians: Komar 1939, no. 6 .

42 Komar 1937, no. 8.

43 Zyz 1931, no. 3.
} 


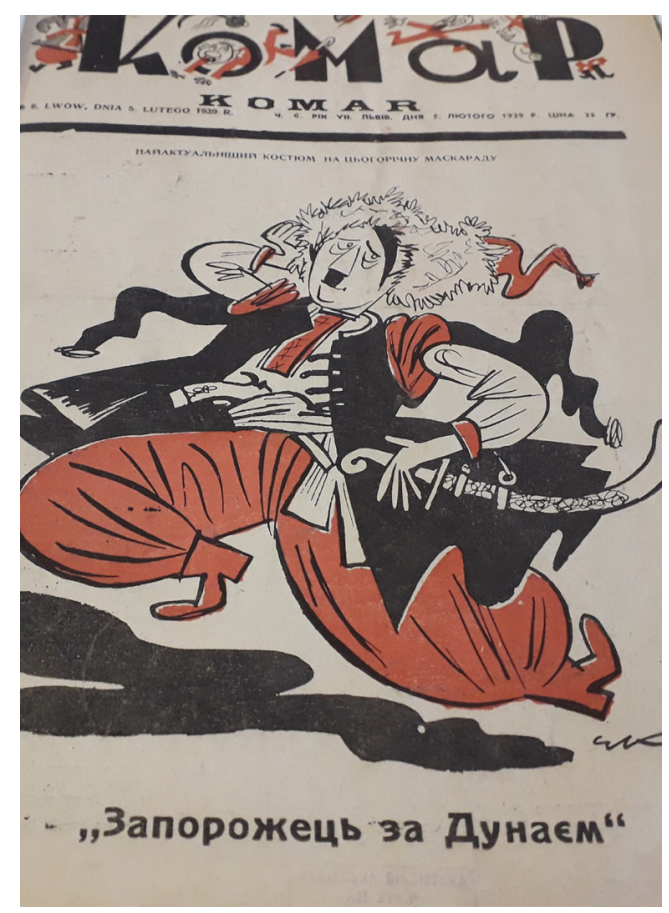

Figure 4. "Zaporozhets za Dunayem." Image of Adolf Hitler as a "Ukrainian Cossack," presented by Komar in the late 1930s.

Source: Komar 1939, no. 6.

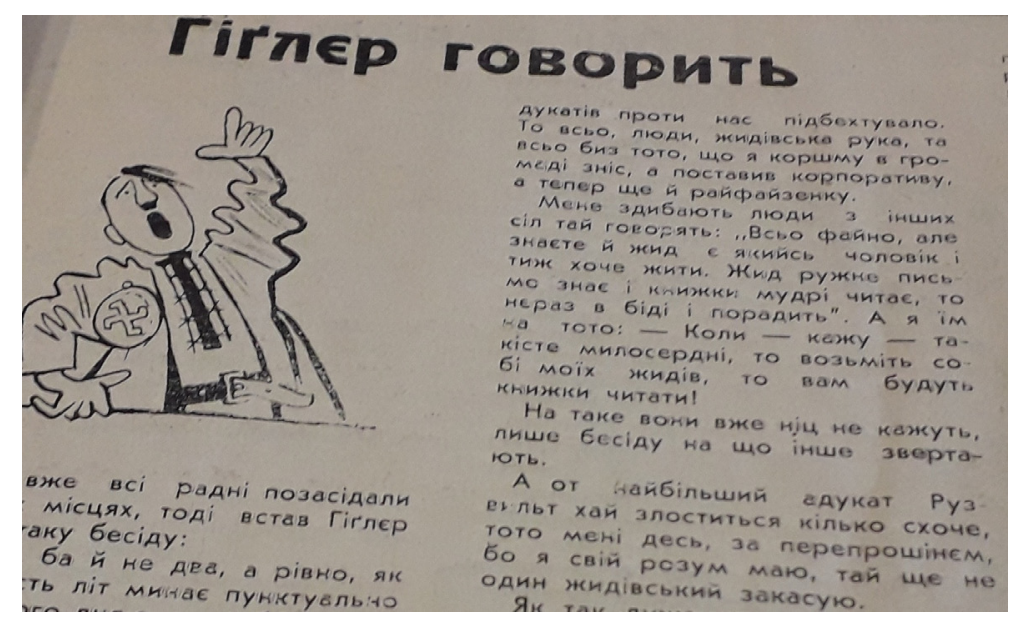

Figure 5. "Higler speaking." Image of Adolf Hitler as a "Ukrainian village head," presented by Komar in the late 1930s.

Source: Komar 1939, no. 6. 


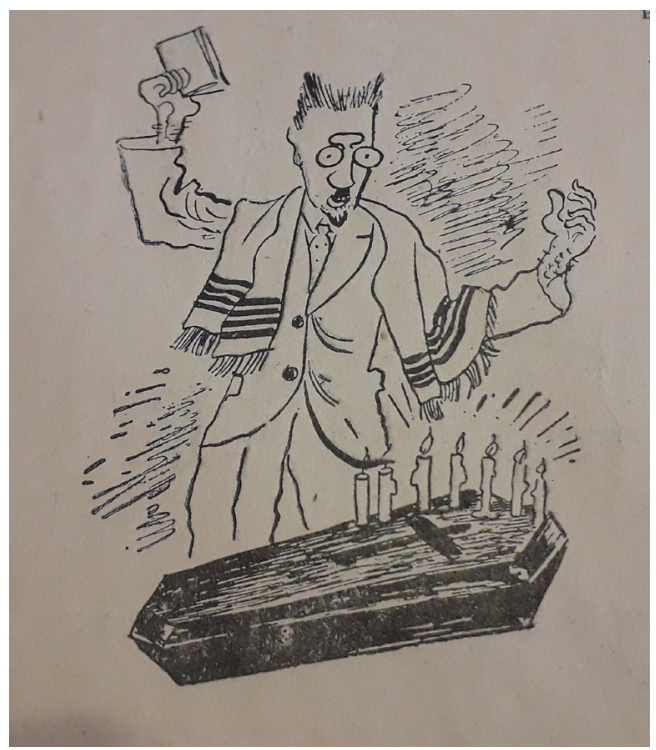

Figure 6. Image of Mykhailo Rudnytskyi as a "Jew-mason."

Source: Komar 1937, no. 8.

So, what image did these journals aim to create through these caricatures? First, the Rudnytskyi family was portrayed as a separate clan that tried to cover different spheres of Ukrainian life (including politics, literature, music, and the women's movement). Second, the level of internal solidarity of the members of this family was absolutized in their willingness to always come to the aid of each other. Third, all their activities and behavior were explained by their Jewish origins. According to Serge Moskovici's theory of social conception, a simplified image of perception and explanation of more complex phenomena is a convenient way of forming a certain kind of thinking among the masses. After all, the idea was the match of the image. ${ }^{44}$ Thus, these cartoonists, in focusing primarily on the peasants and the rural intelligentsia, tried to weaken the real or imagined influence of the Rudnytskyi family on Ukrainian cultural and political life in interwar Galicia.

\section{"The Rudnytskyi problem" in the writings of Galician Ukrainian cultural and political figures}

One of the first texts in interwar Galicia to critique the Rudnytskyi family was a booklet published by Yaroslav Tsurkovsky in $1926 .{ }^{45}$ This was in response to a devastating article by Mykhailo Rudnytskyi in Dilo, in which he criticizes Tsurkovsky's speech and

\footnotetext{
${ }^{44}$ Moscovici 2001: 31.

45 Tsurkovskyi 1926: 1-7.
} 
creativity with undisguised sarcasm. ${ }^{46}$ Tsurkovsky decided to defend his "good name," publishing several dozen copies of a brochure dedicated almost exclusively to criticism of Mykhailo Rudnytskyi. By creating a negative image for prospective readers, Tsurkovsky tried to use Rudnytskyi's Jewish origins in his criticism: "Dr R-y, as a Jew of origin, having Semitic blood, wrote that the critic Chwili is understood in Ukrainian poetry the way he is in the Talmud." ${ }^{47}$ Describing the essence of the conflict with Rudnytskyi, Tsurkovsky pointed to their ideological differences: "Proof of this is the fact that in the lyric-erotic and epic-philosophical of my poetry, Dr R-y the least did not show aloud his racial intolerance. But in the case of phrases against the bourgeoisie[...], Dr R-y is already roaring with an impotent blast." 48

Significantly, even in his criticism of Mykhailo Rudnytskyi, Tsurkovsky did not forget to mention his brothers Anton and Ivan, disparaging them as well. ${ }^{49}$ Of course, this brochure was purely polemical and quickly forgotten, with practically no consequences. However, the tactics used by Tsurkovsky in the brochure were important. Using "racial" arguments, he tried to explain that Mykhailo Rudnytskyi's attitude towards him was a result of Rudnytskyi's Jewish roots. He was in this way biased in his assessment of the Ukrainian poet.

However, Rudnytskyi's most notable criticism in the public space came not from Tsurkovsky's brochure, but from the journal Visnyk. Its editor, Dmytro Dontsov (18831973), signed, among other things, the section "From the press film" with the initials "ML." This section was highly critical of the Rudnytskyis, including Mykhailo, with whom Dontsov fought for the title of the foremost literary critic in Galician Ukraine. In the context of this struggle in the literary field, it is advisable to consider Dontsov's texts. It worth noting that allusions to the Rudnytskyi's Jewish origins had been appearing in Dontsov's articles since the mid-1930s. ${ }^{50}$ One of the first such articles is dated to $1935 .{ }^{51}$ In it, Dontsov mentions an article by the Polish-Jewish publicist and writer Tadeusz Golender on Ukrainian literature. Dontsov had criticized Golender's over-approving attitude towards Mykhailo Rudnytskyi, so Dontsov proved it not only by Rudnytsky's close ties to Polish culture. Dontsov further stated: "For the same motives (and maybe racial motives?) - the whole the Rudnytskyi's family will be interested in Mr. Golender," 52 making an obvious hint at the roots of the Rudnytskyi family. In another article, contrasting Mykhailo Rudnytskyi with his outlook and vision of European culture, Dontsov states that he did not need (hinting at Rudnytskyi) a Europe of decay, a Europe of snobs, a Europe of Barbusse, Gides and Jews because this is not the Europe that Visnyk promotes. ${ }^{53}$ When a literary competition was held in 1936 , one of the members of the jury

46 Dilo 1926, no. 91.

47 Tsurkovskyi 1926: 5.

48 Ibid.: 6.

49 Ibid.: 5 .

50 This is most likely because since 1933 anti-Semitic motives were intensified in Dontsov's texts. This can be explained by his belief that Jews were a mainstay of the communist regime in the USSR, as well as the influence of Nazi ideology on Dontsov: Zaitsev 2013: 195; More about Dontsov's anti-Semitism see: Kurylo 2014: 233-258.

51 Visnyk 1935, Book IX: 687.

52 Ibid.

${ }^{53}$ Visnyk 1936, Book IV: 312. 
was Mykhailo Rudnytskyi. Dontsov, protesting against the decision of the jury to award Yuri Kosach and not Yevgeny Malaniuk, wrote that Rudnytskyi "has nothing to say about Aryan authors because he is from the origin and the spirit - the semi-Semites." 54 Dontsov used that same term "semi-Semite" when he criticized articles of the journal Nazustrich: "It is funny that the body of yesterday's councilors and semi-Semites has been touted by the Ukrainian people!" 55 Dontsov pointed to the special sensitivity of Mykhailo Rudnytskyi to the "Jewish theme" in an article on the 20th anniversary of the death of famous Ukrainian writer Ivan Franko. ${ }^{56}$ Dontsov stressed: "What drew the second critic in Dilo from Franko's legacy? His "sensitive attitude towards the Jews [...]." ${ }^{7}$ Dmytro Dontsov "instrumentalized" the origin of Mykhailo Rudnytskyi, trying to explain to a wider range of readers his behavior vis-à-vis his Jewish origins. Mykhailo Rudnytskyi appeared in Dontsov's articles as a foreign Jew, a "Semi-Semite" as he wrote, to whom everything Ukrainian was foreign.

The "Rudnytskyi's problem" and the question of their identity arose among some Ukrainian figures even in private correspondence. Probably the most typical example here was a series of letters by Petro Kozhevnykov ${ }^{58}$ to one of Osyp Nazaruk's acquaintances. ${ }^{59}$ The following quote from a letter by Kozhevnykov is important to understanding the representations of the Rudnytskyi's family among some Ukrainian nationalists:

Always and every step of the way, among Ukrainians - as needed and among foreigners - I blatantly violated the Rudnytskyi problem. I consider them a completely alien element in Ukrainian society. Their origin tells me everything. For them, there is nothing sacred in Ukrainian life. All their "activities" - politics, literature and music - are determined solely by selfish-materialistic motives. This is quite natural because it is inherent in their race. ${ }^{60}$

In the same letter Kozhevnykov characterizes the activities of Ivan Kedryn-Rudnytskyi: "His 'line' is an unprecedented blend of upism-uvizm-uenerism ${ }^{61}$ with a large dose of Jewish arrogance." ${ }^{62}$ In a subsequent letter, Kozhevnykov called the Rudnytskyi's family "parasites on the Ukrainian national body." ${ }^{3}$ Interestingly, Kozhevnykov's arguments in fact correspond to the visual images published in $Z y z$ and Komar. The argumentation here is similar to the caricatures and Dontsov's texts discussed above. The Rudnytskyi family was presented as non-Ukrainians, and "Others,"

54 Visnyk 1936, Book III: 229.

55 Visnyk 1936, Book VII-VIII: 607.

56 Ibid.: 587.

57 Ibid.

${ }^{58}$ CDIAL, Fond 359, desc. 1, case 261: 1-31; Petro Kozhevnykov (1896-1980) a participant in the revolution of 1917-1921, served in the army of the UNR. In the 1920s, he headed the Union of Ukrainian Fascists (SUF) in exile. He participated in the Constituent Congress of Ukrainian Nationalists in 1929 and became a member of the Leadership Organization of Ukrainian Nationalists (OUN). He was suspected of being linked to German and Soviet intelligence: Pekhiv 2008: 137.

59 The name of the addressee is "Alex." The surname is unknown.

${ }^{60}$ CDIAL, Fond 359, desc. 1, case 261: 11.

${ }^{61}$ Kozhevnykov hinted here that Ivan Kedryn-Rudnytskyi as a member of the UNDO maintained contacts with Yevhen Konovalets (1891-1938), the leader of the Ukrainain Military Organization (UVO). Kedryn-Rudnytskyi met with Konovalets in the period of the Ukrainian People's Republic (UPR)/Ukrainain National Republic (UNR).

62 Ibid.

63 Ibid.: 13. 
some kind of "Jewish Trojan horse," occupying various spheres of Ukrainian culture and politics. Again, the behavior of family members was explained by "racial motives." As in the case of Turkovsky, a direct pretext for raising the topic of Rudnytskyi's origins was a conflict between Kozhevnykov and some members of the family (Ivan and Milena).

The well-known Ukrainian writer Ulas Samchuk (1905-1987), in a letter to Dmytro Dontsov, expressed no doubts about the essence of Mykhailo Rudnytskyi. ${ }^{64}$ Likewise, the journals edited and written by Mykhailo Rudnytskyi were described by Leonid Mosendz (1897-1948) in a letter of 1933 to Dmytro Dontsov, in which he ironically describes the journal $M y$ : " $M y$ - this seems to be, and will remain, a model of a pure Jewish anecdote: the Jew often says so about himself in the 1st person!." ${ }^{65}$ In another letter describing Heinrich Heine's work, Mosendz stated: "His irony is full of purely Jewish mockery and Jewish skepticism [...] He is a product of purely Jewish spirit that feeds himself through the German language. And his conversion did not destroy the Jew in him." ${ }^{66}$ For a number of Ukrainian integral nationalists, in particular some of the authors of Visnyk, such concepts as "Jew," "Jewish," "semi-Semite," become synonymous with the negative, destructive, and all that is alien to Ukrainians. Accordingly, in public space, like in private correspondence, these terms were used to smear opponents.

An important point to make here, the image of the Rudnytskyi's family as "Jews" occupied Ukrainian culture and "parasitizing on the Ukrainian national body" was only one of the images and by far not the most common. Most of the Ukrainian Galician intelligentsia in the interwar period perceived the Rudnytskyis as Ukrainian. Their origins were known to all and often discussed in family circles ${ }^{67}$ Amid a considerable number of Galician Ukrainians, and later of the Ukrainian emigration concerning the origin of the Rudnytskyi's family, it became canonical to say that Olga Rudnytska, despite her ancestry, was able to provide education to prominent Ukrainian figures. ${ }^{68}$ The very fact that members of the Rudnytskyi family managed to gain leading positions in various spheres of the political and cultural life of Ukrainians in interwar Galicia suggests that most Ukrainians did not consider them as "Others." It seems doubtful that Ivan and Milena Rudnytska would be allowed to hold important positions in political parties if they were considered to be "Jewish exiles." Similarly, it would be unlikely that Mykhailo Rudnytskyi would become co-editor of Dilo, one of the largest Ukrainian newspapers in the 1930s, if Ukrainians had considered him an "Other." Therefore, we are dealing not with one single image of the Rudnytskyi's family, but with a plurality of images. It was most likely the Rudnytskyis' successes in the public sphere that led to a campaign to discredit

${ }^{64}$ Complaining to Dontsov that he didn't publish reviews of his works in the "Visnyk," Samchuk notes: "There is discreetly silent for the second book. Moishe Rudnytskyi (Mykhailo - I.C.) will always tell some nonsense." Zaitsev 2019: 262-263.

65 Svarnyk 2000: 511.

${ }^{66}$ Ibid.: 526.

${ }^{67}$ Larysa Krushelnytska in her memoirs cites the words of her grandmother, who said that Rudnytskyi's helps to get out of every situation by "doping" from a significant portion of Jewish blood: Krushelnytska 2018: 404.

${ }^{68}$ Striking example of this statement of Ostap Tarnavsky's memoir: "There I had the opportunity to meet the energetic grandmother of Ivan (her family name was Ida Spiegel) - that energetic woman who, after the death of her husband Ivan Rudnytsky, was able to raise five children on prominent figures of Ukrainian cultural and social life." Tarnavskyi 1986: 68. 
them in the eyes of the rest of Galician Ukraine. Their origins provided convenient fuel for the criticisms from their opponents. ${ }^{69}$

How did the Rudnytskyi family react to the images spread by their enemies? The most logical thing in that situation would be to not respond publicly to the reproaches of Jewish origins. The public reaction to such kinds of criticism, as the story with KedrynRudnytskyi showed, could damage their reputation. Rudnytskyi therefore employed a strategy of disregard, not wanting to focus public attention on this issue. However, this did not mean that these images provoked no reactions. In one of his letters published on the occasion of the publication of his book Between Idea and Form, Mykhailo Rudnytskyi complained to the addressee that he distributed all available copies to different categories of acquaintances. Ironically bitter, Rudnytskyi noted that much can be learned from them: "For the copy you give them, you can hear the real truth: that you are a Freemason, a Jew, a Bolshevik, and a Liberal." 70 However, such public responses were the exception, and not the rule.

\section{Conclusions}

Analyzing the perceptions of the Rudnytskyi family among the Ukrainian population of interwar Galicia, it is worth noting that we are dealing not with one single "image," but at least several competing images. These images differed depending on the environments that produced them. Some Ukrainian nationalists, including the authors circulating Visnyk and the editorial boards of $Z y z$ and Komar had shaped the image of the Rudnytskyi's family as "Others" to the Ukrainian nation. Their Jewish origin was exploited in the creation of their negative image. They tried to portray the Rudnytskyis as "Zelmans" - a Jewish family who, with their private interests, occupied various spheres of Ukrainian life. This image was not the only one, but neither was it dominant. Another image of the Rudnytskyi's family was that of a talented family which had provided Ukraine with a whole galaxy of talented figures. Over time, already in emigration, this positive image became dominant, completely casting aside the negative image that had prevailed in the interwar period. The negative image of the Rudnytskyi's family between the wars spread through several channels of information, both in the public sphere (visual images / caricatures, journal articles, etc.), and in private (correspondence, conversations). The positive image spread largely privately through communication with members of the family. In the formation of the negative image of the Rudnytskyi's family, caricatures played the role of a simplified iconic representation for the wider masses. Meanwhile, the texts contained elements of a conceptual nature intended for a large, narrow audience. It is

${ }^{69}$ Even agents of the NKVD of the USSR pointed to this, in one of the memorandum notes: "The Rudnytskyi family (three brothers and sister) generally played a role in Lviv in the last years before the war. They were the children of a Ukrainian and a Jew, which is why the reactionary Lviv Ukrainian press often had attacks against and caricatures of the Rudnytskyis": HDA SZRU. Ukrainska emihratsiia 20-30 rokiv mynuloho storichia $v$ arkhivnykh dokumentakh rozvidky (chastyna №1). Ynye ukraynskye polytycheskye techenyia $v$ Polshe: 71 .

70 At this point Mykhailo Rudnytskyi made a clear allusion to Dontsov and the Visnyk authors: Nazustrich 1934, no. 18. 
difficult to answer unequivocally the question of the influence of these images on the behavior and identity of the Rudnytskyi family, most of whom tried to ignore the topic. In general, the available sources do not indicate the presence of any kind of "stigma identity" among the family. This also indicates their successful integration into the Ukrainian milieu. Their choice of Ukrainian identity remained with them throughout their lives. However, Rudnytskyi's perception of the public campaign against them, their attitude toward Jewish origin and Jews in general, remains an issue and warrants further research in this direction.

\section{ABBREVIATIONS}

CDIAL - Central State Historical Archives of Ukraine in Lviv

HDA SZRU - Sectoral State Archive Foreign Intelligence Service of Ukraine

UNDO - Ukrainian National Democratic Alliance

UVO - Ukrainian Military Organization

UPR - Ukrainian People's Republic

UNR - Ukrainian National Republic

\section{BIBLIOGRAPHY}

\section{Archival sources}

CDIAL, Fond 359, desc.1, case 261.

\section{Printed sources}

Charnetskyi, A. (2001), Spomyny z moho zhyttia [Memories of my life], Kyiv.

Kedryn, I. (1976), Zhyttia-podii-liudy [Life-events-people], New York.

Krushelnytska, L. (2018), Rubaly lis... Spohady halychanky [Chopping forests... Memories of the Galician], Lviv.

Lysiak-Rudnytskyi, I. (2019), Shchodennyky [Diaries], Kyiv.

Rudnytska, M. (1998), Z mynuloho rodu Rudnytskykh [From Rudnytsky's past], in: Milena Rudnytska: Statti. Lysty. Documenty [Milena Rudnytska: Articles. Letters. Documents], Lviv.

Rudnytskyi, V. (1970), Nezabutnie davno mynule [An unforgettable long past]: in: Berezhanska Zemlia. Istorychno-memuarnyi zbirnyk [Berezhanska zemla. Collection of historical and memorial materials], New York.

Svarnyk, H. (2000), Lysty Leonida Mosendza do Dmytra Dontsova za 1931-1934 roky [Letters of Leonid Mozendz to Dmytro Dontsov for 1931-1934], Zapysky Naukovoho tovarystva imeni Shevchen$k a-$ Notes of the Shevchenko Scientific Society, vol. 239, Lviv.

Tarnavskyi, O. (1986), Ivan Lysiak-Rudnytskyi - liudyna dystsypliny dumky (osobysti sposterezhennia) [Ivan Lysiak-Rudnytsky - a person of discipline thought (personal observations)], Urkainskyi istoryk - Ukrainian Historian, no. 3-4: 91-92.

Tsurkovskyi, Y. (1926), Moia pryliudna vidpovid Mykh. Rudnytskomu. Zbankrotovanyi virshun zahybaiuchoi kliky v litereturno-krytychnomu zamotylycheni [My public answer Mikh. Rudnytskyi. A bankrupt poem of a deadly clique in literary-critical numbness], L'viv.

\section{Press}

Dilo 1926.

Komar 1933, 1934, 1935, 1937, 1938, 1939. 
Nazustrich 1934.

Visnyk 1935, Book IX, 1936, Book III, IV, 1936, Book VII-VIII.

Zyz 1924, 1925, 1930, 1931.

\section{Secondary literature}

Bohachevsky-Chomiak, M. (1988), Feminists Despite Themselves: Women in Ukrainian Community Life, 1884-1939, Edmonton.

Diadiuk, M. (2011), Ukrainskyi zhinochyi rukh u mizhvoiennii Halychyni: mizh hendernoiu identychnistiu ta natsionalnoiu zaanhazhovanistiu [The Ukrainian women's movement in interwar Galicia: Between gender identity and national involvement], Lviv.

Gnoiński, T. (2012), Milena Ewelina Rudnicka-Łysiak (1892-1976) - poseł na Sejm II i III kadencji II Rzeczypospolitej w latach 1928-1935 i jej związki z Siennica, Rocznik Mińsko-Mazowiecki 20: $179-180$.

Hnatiuk, O. (2019), Courage and Fear, Boston, MA.

Hrytsak, Y. (1994), Ivan Lysyak-Rudnytskyi (Narys intelektualnoi biohrafii) [Ivan Lysyak-Rudnytskyi (Essay on intellectual biography)], Suchasnist-Modernity 11: 73-96.

Jarno, W. (2018), Alfred Biłyk (1889-1939) - legionista, komendant Miasta Łodzi, adwokat i wojewoda, in: W. Jarno and P. Waingertner (eds.), Łódzcy bohaterowie 1918 roku, Łódź: 55-79.

Konstantynow, D., and G. Krzywiec (2013), “Obcy i niemili.” Antysemickie rysunki z prasy polskiej 1919-1939, Warszawa.

Kurylo, T. (2014), The "Jewish Question" in the Ukrainian Nationalist Discourse of the Inter-War Period, in: Y. Petrovsky-Shtern and A. Polonsky (eds.), Polin, vol. 26, The Littman Library of Jewish Civilization, Oxford: 233-258.

Kvit, S. (1997), Literaturno-krytychna y zhurnalistska diialnist Mykhaila Rudnytskoho u 1910-1930-kh rokakh [Literary-critical and journalistic activity of Mykhailo Rudnytsky in the 1910s-1930s], candidate's thesis, Kyiv.

Mazower, M. (1999), Dark Continent: Europe's Twentieth Century, New York.

Moscovici, S. (2001), Social Representations: Explorations in Social Psychology, New York.

Neumann, I.B. (1996), Russia and the Idea of Europe: A Study and International Relations, London.

Neumann, I.B. (1998), Russia as Europe's Other, Journal of Area Studies, 6 (12): 26-73.

Neumann, I.B. (1999), Uses of the Other. "The East" in European Identity Formation, Minneapolis.

Pawłyszyn, O. (2017), Rachmańska Wielkanoc - tradycja i interpretacje, in: M. Trojan (ed.) W kręgu tradycji kulturowych środkowo-wschodniej Europy. Tom poświęcony pamięci Profesora Edwarda M. Pietraszka, Wrocław.

Pekhiv, V. (2008), Italiiskyi vector zovnishnoi polityky OUN [Italian vector of OUN foreign policy], Visnyk Natsionalnoho universytetu "Lvivska politekhnika" - Bulletin of the National University "Lviv Polytechnic," no. 612: 136-140.

Sawa, M. (2016), Ukraiński emigrant. Działalmość i myśl Iwana Kedryna-Rudnyckiego (1896-1995), Lublin.

Shkandrij, M. (2009), Jews in Ukrainian Literature. Representation and Identity, New Haven.

Snitsarchuk, L. (2003a), Komar, in: M. Romaniuk and M. Halushko (eds.) Ukrainski chasopysy Lvova 1848-1939 rr.: Istoryko-bibliohrefichne doslidzgennia: U 3 t. T.3, Kn. 2. 1929-1939, Lviv.

Snitsarchuk, L. (2003b), Zyz, in: M. Romaniuk and M. Halushko (eds.) Ukrainski chasopysy Lvova 1848-1939 rr.: Istoryko-bibliohrefichne doslidzgennia: U 3 t. T.3, Kn. 1. 1920-1928, Lviv.

Vovchko, V. (2016), Asymiliatsiini protsesy yevreiskoho naselennia Halychyny u druhii polovyni XIX - na pochatku XX st. [Assimilation processes of the Jewish population of Galicia in the second half of the 19th - early 20th centuries], candidate's thesis, Lviv.

Zaitsev, O. (2013), Ukrainskyi intehralnyi nationalism (1920-1930-ti roky): Narysy intelektualnoi istorii [Ukrainian integral nationalism (1920s-1930s): Essays on intellectual history], Kyiv. 
Zaitsev, O. (2019), Natsionalist u dobi fashyzmu. Lvivskyi period Dmytra Dontsova 1922-1939 roky. Nacherk intelectualnoi biohrafii [A nationalist in the age of Fascism. Dmytro Dontsov's Lviv period 1922-1939. Sketch of an intellectual biography], Kyiv.

\section{Online sources}

HDA SZRU. Ukrainska emihratsiia 20-30 rokiv mynuloho storichia v arkhivnykh dokumentakh rozvidky (chastyna №1). Ynye ukraynskye polytycheskye techenyia $v$ Polshe [Ukrainian emigration of the twenties and thirties of the last century in archival intelligence documents (part 1). Other Ukrainian political movements in Poland], http://szru.gov.ua/uploads/files/news-gal-arhiv/part_1_2016.pdf (Accessed: 25 May 2019).

Moskovychy, S. (1995), Sotsyalnie predstavlenyia: ystorycheskyi vzghliad [Social representations: A historical view], Psykholohycheskyi zhurnal - Psychological Journal, http:/web-local.rudn.ru/ web-local/uem/ido/psix_lich/ch10_2.html (Accessed: 23 November 2018).

Ryndyk, S. (1961), "Yide, yide Zelman!” [Goes, goes Zelman], http://www.yatran.com.ua/articles/596. html (Accessed: 22 November 2018).

Yide, yide Zelman abo Tsikava storinka z istorii Drohobycha [Goes, goes Zelman or an interesting page on the history of Drohobych], http://droginfo.com.ua/content/view/5924/ (Accessed: 21 October 2018). 